\title{
Conserving agrobiodiversity amid global change, migration, and nontraditional livelihood networks: the dynamic uses of cultural landscape knowledge
}

\author{
Karl S. Zimmerer ${ }^{1}$
}

\begin{abstract}
I examined agrobiodiversity in smallholder cultural landscapes with the goal of offering new insights into management and policy options for the resilience-based in situ conservation and social-ecological sustainability of local, food-producing crop types, i.e., landraces. I built a general, integrative approach to focus on both land use and livelihood functions of crop landraces in the context of nontraditional, migration-related livelihoods amid global change. The research involved a multimethod, case-study design focused on a cultural landscape of maize, i.e., corn, growing in the Andes of central Bolivia, which is a global hot spot for this crop's agrobiodiversity. Central questions included the following: (1) What are major agroecological functions and food-related services of the agrobiodiversity of Andean maize landraces, and how are they related to cultural landscapes and associated knowledge systems? (2) What are new migration-related livelihood groups, and how are their dynamic livelihoods propelled through global change, in particular international and national migration, linked to the use and cultural landscapes of agrobiodiversity? (3) What are management and policy options derived from the previous questions? Combined social-ecological services as both cultivation and food resources are found to function in relation to the cultural landscape. Results demonstrated major variations of maturation-based, phenologic traits and food-use properties that are cornerstones of the landrace-level agrobiodiversity of Andean maize. Knowledge of these parameters is widespread. Linkage of these production and consumption functions yields a major insight into dynamics of Andean maize agrobiodiversity. Concurrently, this smallholder cultural landscape has become increasingly dependent on new rural conditions, especially increased livelihood diversification and migration amid growing peri-urban influences. Viability of landrace-level maize agrobiodiversity between 2006 and 2012 is shown to have occurred amid a transition toward the integral roles of multiple migrationrelated groups, namely women farmers, consumers, and local business owners; migrants; field caretakers; and local in-migrant laborers. The nontraditional social networks among these livelihood groups must be incorporated into analysis and planning of the design, participation, and monitoring of management and policy options for cultural landscapes ensuring the use, in situ conservation, and sustainability, including ecosystem services, of food plant landraces in global agrobiodiversity hot spots.
\end{abstract}

Key Words: cultural landscapes; knowledge systems; maize; phenology-based adaptive capacity; social networks of migration

\section{AGROBIODIVERSITY OF MAIZE LANDRACES IN CULTURAL LANDSCAPES}

My research is focused on the social-ecological dynamics of agrobiodiversity in the context of cultural landscapes to offer new management and policy options for in situ conservation and sustainability. It is motivated by the growing emphasis on agricultural biodiversity, or agrobiodiversity, as a foundation of sustainability "that includes all components of biological diversity of relevance to food and agriculture, and ... agricultural ecosystems" (CBD 2013a:1, b). Four principal components of agrobiodiversity are highlighted (Fig. 1): (1) genetic resources for food and agriculture; (2) biodiversity that supports ecosystem services of agriculture; (3) abiotic factors, e.g., climate; and (4) socioeconomic and cultural dimensions. This new governance perspective of the Convention on Biological Diversity reflects the emphasis on global change, intensification, and ecosystem services in the use of agrobiodiversity for sustainability of land, water, and livelihood resources (Vandermeer et al. 1998, Swift et al. 2004, Jarvis et al. 2007, Scherr and McNeely 2008, Zimmerer 2010a, 2013).

These trends helped fuel the Millennium Ecosystem Assessment, which describes agricultural biodiversity as combining "domesticated biodiversity," i.e., planned, and "associated biodiversity" (Cassman and Wood 2005:756). Although blurred in practice, the distinctions of planned and associated biological diversity are being commonly applied to agroecosystems
Fig. 1. Cultural landscapes in relation to the major components of agrobiodiversity as defined in the Convention on Biological Diversity, with examples and conceptual framework from this study.

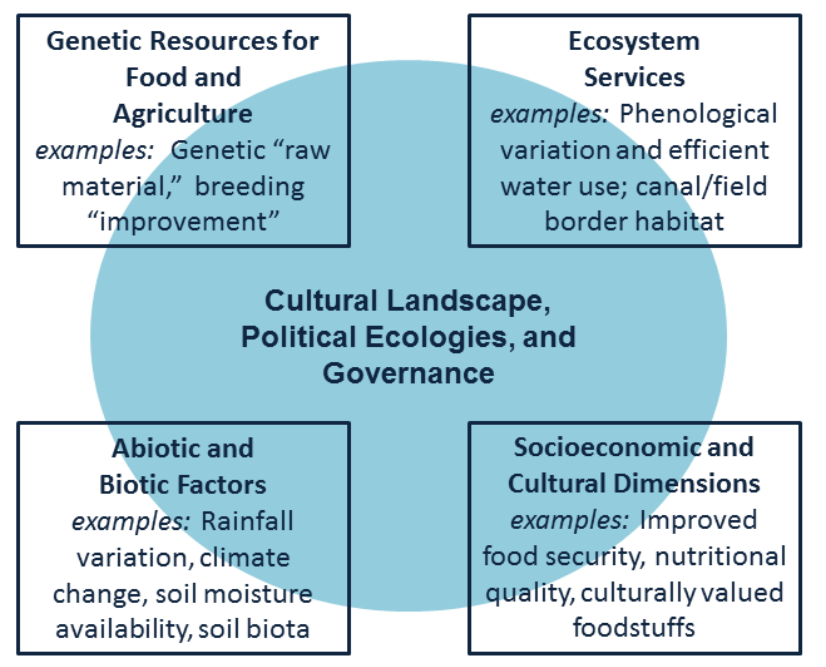


(Vandermeer et al. 1998, Swift et al. 2004, Tscharntke et al. 2005, Méndez et al. 2010). Planned agrobiodiversity at the taxonomic level of farmer crop varieties or cultivars, often referred to as landraces, is operationalized locally (Zimmerer 1996, 2013, Brush 2004, Love and Spaner 2007, van Etten et al. 2008, de Haan et al. 2010). Such landrace-level agrobiodiversity can deliver important ecosystem services through beneficial impacts on pest control, plant diseases, and soil nutrient cycling and biota (Altieri 1999, Jackson et al. 2007, Hajjar et al. 2008, Bianchi et al. 2013, Chateil et al. 2013, Vanek and Drinkwater 2013). However, surprisingly, the new emphasis on agroecosystem services has only begun to examine the potentially integral social-ecological functioning of landrace-level agrobiodiversity for basic-needs uses as land, water, and food resources. My research is focused on this research gap using the case of maize landraces, in Bolivia, in which the phenologic range of crop maturation periods can function to stagger cultivation and the use of water resources, while this landrace-level agrobiodiversity also furnishes culturally valued food and nutritional benefits.

The concept of cultural landscapes, which derives from the idea of "an area, as perceived by people, whose character is the result of the action and interaction of natural and/or human factors" (Plieninger and Bieling 2012a:7; see also Council of Europe 2000, Schaich et al. 2000), promises to become integral as a framework in understanding the broad socio-cultural and land-use-specific functional components of agrobiodiversity along with the analysis and recommendation of innovative policy and management options for in situ conservation and sustainability. To date, however, these linkages have not been a focus of the increased emphasis on agrobiodiversity and its future. Addressing this gap is timely and central to this research. Indeed, each agrobiodiversity component, as defined previously, is integrally related to cultural landscapes (shading in Fig. 1). For example, the dynamics of cultural landscapes related to agrobiodiversity and ecosystem services, i.e., the second component mentioned previously, are necessary to understand "why agricultural land use has ... effects on biodiversity and related ecosystem services" (Tscharntke et al. 2005:857; see also Jackson et al. 2007). Moreover, landrace-level agrobiodiversity is concentrated globally in the cultural landscapes of a wide range of areas (Perales et al. 2003, Brush 2004, van Etten 2006, Brush and Perales 2007, van Etten and de Bruin 2007, Nabhan 2008, van Etten et al. 2008, Zimmerer 2010a, 2011). It occurs in smallholder and indigenous farm landscapes; spaces in and near protected areas, i.e., "matrix environments" (Perfecto and Vandermeer 2010); gardens along with peri-urban and urban farming (Lerner and Appendini 2011, Van der Stege et al. 2012); and organic and other eco-agricultural alternatives (Scherr and McNeely 2008).

The cultural landscape framework enables me to investigate the agrobiodiversity of several food plants, including unique maize landraces, in the tropical Andes mountains of western South America, particularly the inter-Andean valleys and foothills (Fig. 2). In Bolivia and Peru, for example, these cultural landscapes support concentrations of maize agrobiodiversity that are of paramount global importance (Brandolini 1970, Goodman and Stuber 1983, Perales et al. 2003, Sánchez et al. 2006, Zimmerer 2013). Bolivia alone produces $33-40$ races of maize, $\sim 8-10 \%$ of the total of Latin America and the Caribbean; Bolivian maize agrobiodiversity per unit area at the landrace level equals or exceeds any other country (Ramírez et al. 1960, Goodman and Stuber 1983, Ávila et al. 1998, Zimmerer 2013).
Fig. 2. Examples of major cultural landscapes of the agrobiodiversity of Andean maize in western South America; enumerated examples show Andean valley and foothill landscapes.

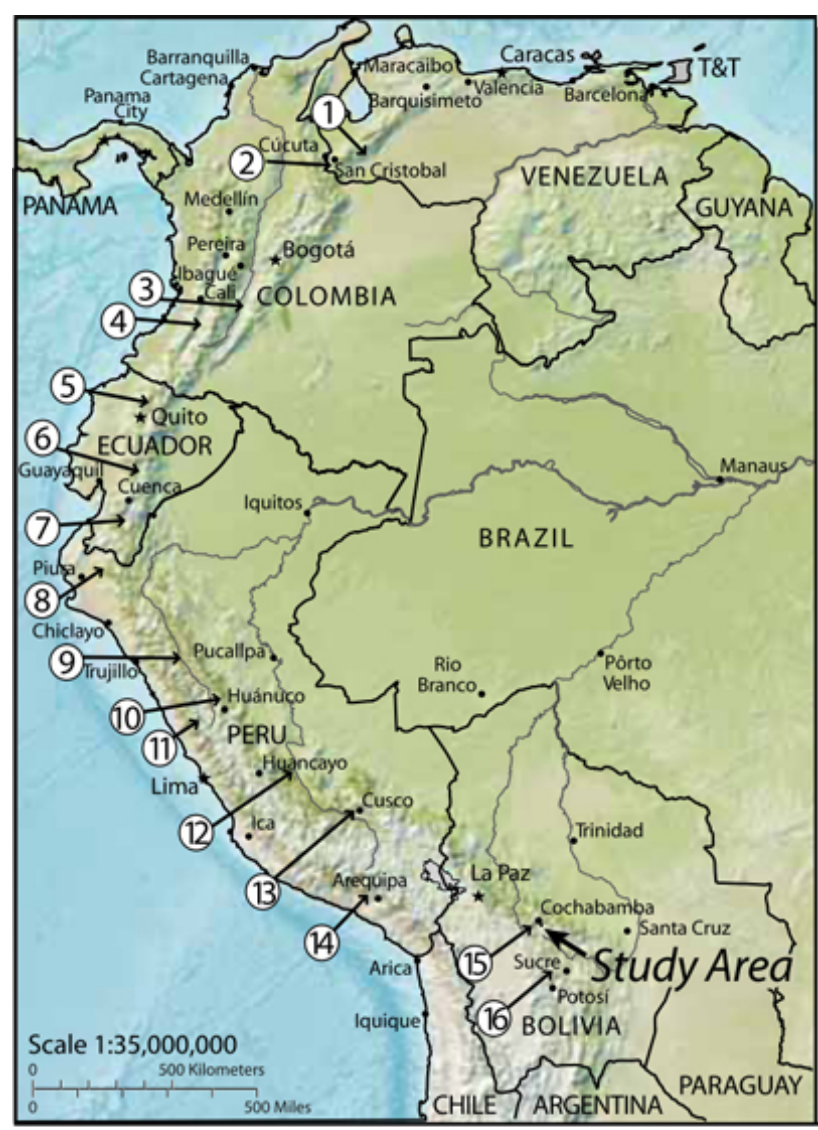

Key

1. Upper Chama Valley

2. Upper Apure Valley

3. Upper Magdalena Valley

4. Upper Cauca Valley

5. Pimampiro/Ibarra (RIVER?)

6. Riobamba (Chambo Valley)

7. Loja (Cuxibamba Valley)

8. Upper Piura

9. Middle-Upper Marañón Valley

10. Upper Huallaga Valley

11. Santa Valley/Callejon de Huaylas

12. Upper Ucayali-Mantaro Valley

13. Cusco (Urubamba Valley)

14. Arequipa and Colca Valley

15. Cochabamba Valleys

16. Sucre and Upper Pilcomayo Valley 
Table 1. Framework of cultural landscapes with selective integration of concepts.

\begin{tabular}{|c|c|c|c|c|}
\hline Conceptual Approach & Key Source(s) & General Usefulness & $\begin{array}{l}\text { Specific Concept(s)/Use } \\
\text { in this Research }\end{array}$ & Limitations \\
\hline Cultural Landscapes & $\begin{array}{l}\text { Plieninger and Bieling } \\
(2012 b)\end{array}$ & $\begin{array}{l}\text { Broad comprehensive } \\
\text { framework }\end{array}$ & $\begin{array}{l}\text { Integrates the utilization } \\
\text { of specific conceptual } \\
\text { approaches in this study } \\
\text { (as shown in this table) }\end{array}$ & $\begin{array}{l}\text { Does not include in- } \\
\text { depth conceptual } \\
\text { analytics for certain } \\
\text { social-ecological issues }\end{array}$ \\
\hline $\begin{array}{l}\text { Coupled Human- } \\
\text { Natural and SES } \\
\text { (Social-Ecological } \\
\text { Systems) }\end{array}$ & $\begin{array}{l}\text { Liu et al. (2007); Ostrom } \\
\text { (2009) }\end{array}$ & $\begin{array}{l}\text { Focus on resource } \\
\text { management } \\
\text { interactions }\end{array}$ & $\begin{array}{l}\text { Social-ecological } \\
\text { resilience }\end{array}$ & $\begin{array}{l}\text { Does not include } \\
\text { landscape emphasis }\end{array}$ \\
\hline $\begin{array}{l}\text { Land System and } \\
\text { Sustainability Sciences }\end{array}$ & $\begin{array}{l}\text { Turner et al. (2007); } \\
\text { Kates et al. (2001) }\end{array}$ & $\begin{array}{l}\text { Focus on environment- } \\
\text { development } \\
\text { interactions and global } \\
\text { change }\end{array}$ & $\begin{array}{l}\text { Spatial analysis of land } \\
\text { systems and uses amid } \\
\text { global change }\end{array}$ & $\begin{array}{l}\text { Does not include } \\
\text { emphasis on social } \\
\text { complexity and cultural } \\
\text { identities }\end{array}$ \\
\hline Political Ecology & $\begin{array}{l}\text { Peterson (2000); Turner } \\
\text { and Robbins (2008); } \\
\text { Birkenholtz (2009); } \\
\text { Goldman et al. (2011) }\end{array}$ & $\begin{array}{l}\text { Social complexity and } \\
\text { livelihood-development } \\
\text { interactions }\end{array}$ & $\begin{array}{l}\text { Migration-based } \\
\text { livelihood groups, } \\
\text { gendered, social-power } \\
\text { relations }\end{array}$ & $\begin{array}{l}\text { Does not contain } \\
\text { emphasis on coupling of } \\
\text { human-natural systems } \\
\text { and landscapes }\end{array}$ \\
\hline New Rurality & $\begin{array}{l}\text { Kay (2008); Reardon et } \\
\text { al. (2001) }\end{array}$ & $\begin{array}{l}\text { Livelihood } \\
\text { diversification }\end{array}$ & $\begin{array}{l}\text { Nontraditional } \\
\text { economic activities as } \\
\text { rural socioeconomic } \\
\text { globalization }\end{array}$ & $\begin{array}{l}\text { Does not contain } \\
\text { emphasis on } \\
\text { environmental impacts or } \\
\text { issues }\end{array}$ \\
\hline
\end{tabular}

Integrated analysis of the combined social-ecological functions and use of landraces tied to the changing context of smallholder cultural landscapes is a sizable gap in both current research and the analysis of options for agrobiodiversity management and in situ conservation. Understanding this gap requires conceptualizing the cultural landscapes of this agrobiodiversity as extending from its use as a cultivation resource, e.g., with regard to water availability and climate change, to food for consumption, e.g., diverse nutrition and food processing and preparations, as well as seed for replanting (Carney 2003, Chambers and Momsen 2007, Bellon et al. 2011, Zimmerer 2011, 2012, Calvet-Mir et al. 2012). The multifunctional activities associated with highagrobiodiversity landraces resembles the use of other cultural landscapes combining the nonseparability of food consumption and resource-based production rationales together with ecosystem services (Zimmerer 1996, 2011, Schaich et al. 2010, Plieninger and Bieling 2012a,b). Specifically, the landrace-level agrobiodiversity of maize will be shown to include the multifunctionality of market-based sales, subsistence food, and seed through mobilizing farmers' knowledge of the major features of maturation period and food preparation along with access to resources, technology, and the interactions with nonagricultural ecosystems, e.g., anthropogenic canal-side woodlands (Zimmerer $2010 a, b)$.

At the same time, the cultural landscapes of agrobiodiversity and landrace usages are undergoing accelerated transitions through global environmental and socioeconomic changes (Zimmerer 2013). Global climate change and extensive human migration driven through worldwide market integration impinge directly on hot spots of global agrobiodiversity. My research focuses on the gap concerning global changes and, specifically, migration, i.e., hundreds of millions of people annually, exerting a major and growing influence worldwide on environmental governance, resource use, biodiversity, food, and social-ecological resilience (Adger et al. 2002, Ericksen et al. 2010, Warner 2010, Future Earth 2013). Such migration may either enhance or undermine the use, conservation, and sustainability of landrace-level agrobiodiversity (Zimmerer 2010a, 2013).

Three sets of connected questions guide this research: (1) What are major agroecological functions and food-furnishing functions of the agrobiodiversity of Andean maize landraces, and how are they related to cultural landscapes and associated knowledge systems? (2) What are new migration-related livelihood groups, and how are their dynamic livelihoods propelled through global change, in particular international and national migration, linked to the use and cultural landscapes of agrobiodiversity? (3) What are new management and policy options resulting from the findings in (1) and (2)? To address these questions, I constructed a conceptual framework based on cultural landscapes (Conceptual frameworks) and a mixed-methods design of research (Methods) using a casestudy representative of smallholder farmers in the tropical mountains and foothills of the western South American Andean countries. Focusing on Bolivia's "High Valley"(Fig. 2), the research examines agroecosystem and food functions of maize landraces, corresponding knowledge systems, and the changing dynamics of livelihoods in this global agrobiodiversity hot spot. A final gap being addressed is research methodology designed explicitly to provide the rigorous analysis and recommendations of innovative management and policy options for sustainability and in situ agrobiodiversity conservation.

\section{CONCEPTUAL FRAMEWORKS: LINKING CULTURAL LANDSCAPES AND AGROBIODIVERSITY TO KNOWLEDGE SYSTEMS AND NEW RURALITY}

The concept of cultural landscape offers a versatile framework that is compatible with approaches in the human, cultural, and socialecological sciences (Plieninger and Bieling 2012b; Table 1). I 
selectively integrate elements while recognizing the specific usefulness and limitations of each approach (Table 1), as well as overall differences (see also Zimmerer 2011, Turner 2013). The conceptual framework of cultural landscapes enables the investigation of agrobiodiversity dynamics involving use, knowledge, learning, and livelihood transitions in the context of global changes. It also underscores that greater emphasis must be given to "knowledge systems ... in the monitoring of biodiversity and ecosystem services [in agricultural landscapes]" (Jackson et al. 2012:623). I echo the clarion call of Jackson et al., focusing on the everyday operational knowledge of landrace-level cultivation qualities and food properties that comprise principal functions in cultural landscapes, such as water management and staple nutritional and dietary preparations. This research gap both motivates and requires that the active use of knowledge systems be seen as emerging through changing cultural landscapes and livelihoods, evidencing dynamic cultures and social-power relations (Escobar 1998, Beymer-Farris et al. 2012, Widgren 2012). These knowledge systems are therefore relational and tied to ongoing socioeconomic development and cultural identity making, rather than being static or vestigial. They are also linked via the livelihoods and cultural landscapes of agrobiodiversity users to increasingly multiscale global changes during the past few decades (Batterbury 2001, Bebbington 2001, Kates et al. 2001, Mayer 2002, 2004, Liverman and Vilas 2006, Turner et al. 2007, Lambin and Meyfroidt 2011, Widgren 2012).

Given the previously mentioned trend, the framework of this research also incorporates a focus on the increasing, dynamic interactions of nontraditional livelihood activities with smallholder agrobiodiversity use (Isakson 2009, Zimmerer 2010a). However, a gap in current understanding exists insofar as specific uses of agrobiodiversity and knowledge systems, along with corresponding cultural landscapes, have not been investigated with regard to vital linkages to livelihood groups being formed through nontraditional activities, such as migration. Addressing this lacuna leads my research to extend significantly beyond recent works linking customary aspects of livelihoods, for example, resource endowments and activity portfolios, to agrobiodiversity (Brush 2004, Coomes and Ban 2004, Zimmerer 1996, 2010a, 2011) and ones showing that cultural landscapes generally supporting agrobiodiversity can encompass elements that are both customary and nontraditional (Calvo-Iglesias et al. 2006, Ishizawa 2006). Focus on the significance of nontraditional livelihoods, specifically international and national migration and the resulting agrobiodiversity-related roles of local livelihood groups, is increasingly important as a consequence of global environmental and socioeconomic changes. The rapidly expanding importance of these activities is indicative of "new rurality," which is defined as the expanding transitions in which rural livelihoods, landscapes, and identities increasingly connect to nonfarm activities and nonlocal interactions with urban areas and global phenomena, e.g., international labor migration (Reardon et al. 2001, Mayer 2002, 2004, Kay 2008, Van der Ploeg 2009, Yarnall and Price 2010, Zimmerer 2010a).

Recognizing the influential role of nontraditional livelihood elements amid global change contributes a much-needed perspective on emergent social-ecological properties (sensu Trosper 2005, Cash et al. 2006) integral to both food security (Ericksen et al. 2010) and the current use and ongoing conservation of agrobiodiversity (Zimmerer 2013), rather than it being static or residual as sometimes assumed. Effects of migration, for example, may enhance general biodiversity (Adger et al. 2002, Hecht and Saatchi 2007, Seto 2011), whereas specific impacts on smallholder agriculture can be either positive (Gray 2009) or negative (Jokisch 2002). I build on these important insights to focus specifically on the emerging roles and importance of livelihood processes and groups arising through increased migration. These emergent global change processes provide opportunities for broadening the conservation circle (Gepts 2006), while raising significant new issues of social justice.

Finally, the use and knowledge systems of agrobiodiversity in cultural landscapes, and related frameworks such as land architecture (Turner and Lawrence 2012), must be seen as potentially enabling capacities for social-ecological resilience and ecosystem services (Schaich et al. 2010, Plieninger and Bieling 2012a). Social-ecological resilience in my research refers to the capacity of agrobiodiversity-producing cultural landscapes, and the agroecosystems and food use they support, to respond to stressors and disturbances while maintaining structures and functional processes that include multifunctionality and some degree of socioeconomic power and autonomy. Such approaches need to range from quantitative assessments (Raudsepp-Hearne et al. 2010) to the cultural and socioeconomic empowerment of nonmajority and poorer peoples whose landscapes frequently provide such functions (Erickson 2003, Brosius 2006, Goldman and Turner 2011). In my research, landrace-level agrobiodiversity use and knowledge are considered as enabling capacities for food cultivation amid environmental constraints, e.g., soil moisture, and ensuring food access; these resources can, in turn, aid socialecological resilience in the event of irrigation or rainfall shortages and market uncertainties. At the same time, these resources and services must be seen as intimately and extensively coupled to the surrounding cultural landscapes.

\section{METHODS}

Case-study research was focused in the cultural landscape of the western portion of Bolivia's High Valley, referred to as the "Tarata-Arbieto cultural landscape" (Fig. 3). It is centered on these main settlements extending eastward (Fig. 3, middle and right inset maps in upper panel) and is generally representative of the smallholder agricultural systems of the surrounding High Valley. Much farmland of the Tarata-Arbieto cultural landscape is located atop a low-gradient alluvial fan (2620-2750 $\mathrm{m}$ above sea level) composed of both an irrigated area and rain-fed fields scattered within valley bottom lands. Surrounding uplands of the Tarata-Arbieto cultural landscape reach to $\sim 3100 \mathrm{~m}$ above sea level. Biogeophysical parameters of valley lands, where most agriculture occurs, include semiarid climate (mean $586 \mathrm{~mm} / \mathrm{yr}$, $1958-2010)$, strongly seasonal precipitation ( $86 \%$ November to April), pronounced interannual variability (coefficient $=0.55)$, and ribbon-shaped matrices of anthropogenic, canal-side (riparian) forests and patchwork vegetation including grasses and shrubs (Zimmerer 2010b). Land users are bilingual QuechuaSpanish, with low-to-moderate incomes by national standards. Peri-urban location, i.e., $35-50 \mathrm{~km}$ to the Cochabamba urban area (population 1.1 million), fuels extralocal socioeconomic integration. 
Fig. 3. Geographic details of the Tarata-Arbieto cultural landscape of the western "High Valley" (Valle Alto), Cochabamba, Bolivia.

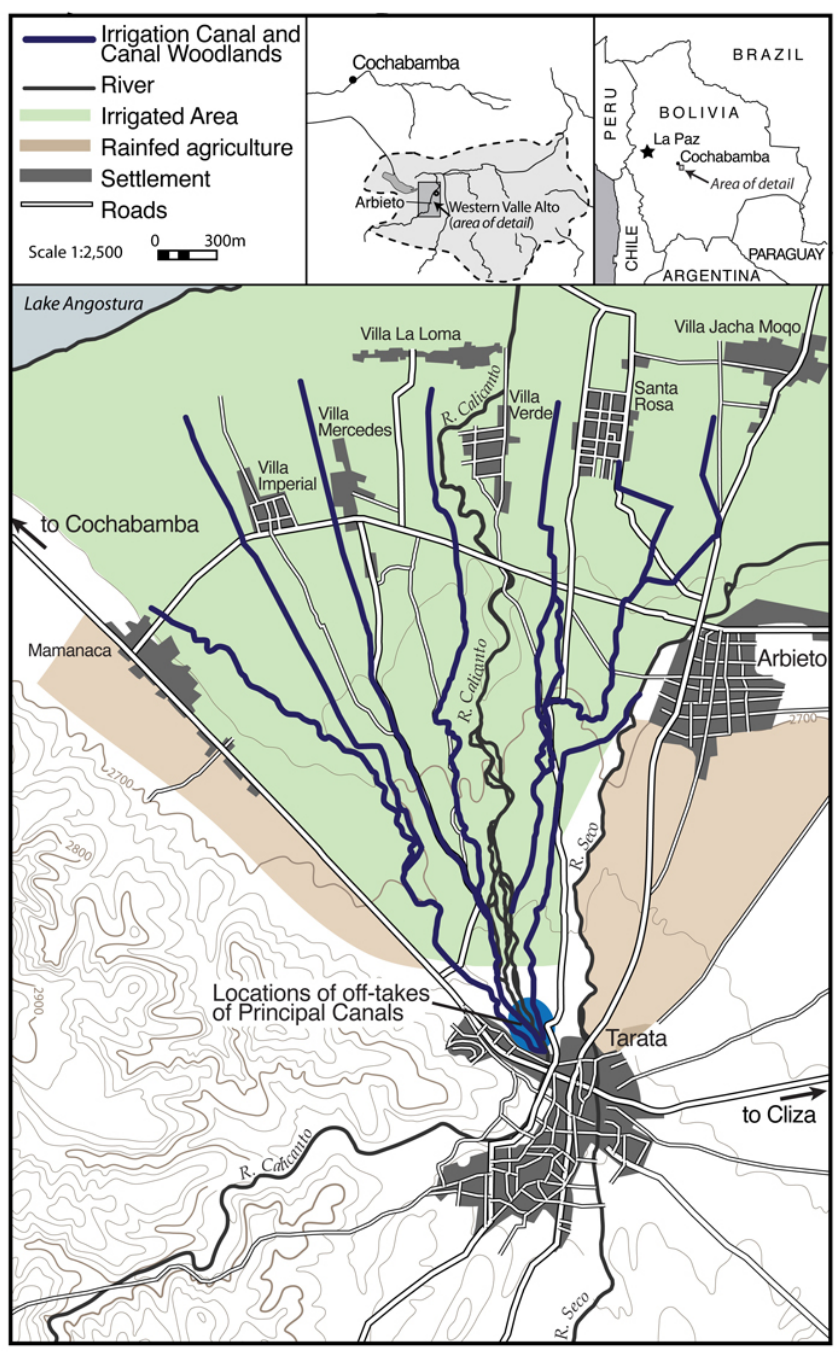

Research methods included the design, implementation, and analysis of a total of 73 semistructured interviews with maize growers chosen through a structured random design using community rosters to ensure inclusion of different livelihood groups; for percentages of each livelihood group, see Results. Interviewees were asked about their knowledge in two domains: (1) awareness of the maturation periods and categories of each maize landrace and (2) food preparations supplied through each landrace. Examples of these questions, pertaining to the kulli landrace, were as follows: "What is your estimate of the maturation period of kulli?" "Which phenology-based category of maturation best applies to kulli?" "For what food use or uses is kulli most well-suited?" Interviewees were also asked about general preferences for landraces and improved varieties. These questions made use of the researcher's analysis of 10 principal maize landraces through field sampling and classification
(Zimmerer 2013). The interviews were recorded and transcribed (1036 pages); each interview was coded to rank full, near-full, or partial knowledge about maturation characteristics and food uses of maize landraces. General information elicited in the interview questions also included ecosystem functions, such as benefits of vegetative cover in areas along fields and irrigation canals, as well as open-ended questions about livelihood changes and strategies; households of 41 of these interviewees included a recent migrant.

A GIS database incorporated high-resolution imagery, i.e., 1:2500 topographic maps and the georectified 2.4-m high-resolution QuickBird image of 14 April 2012, that had been tasked by the project. Major features, such as settlements and irrigation canals, were classified, mapped, and measured as a means of general analysis of the cultural landscape. Field boundaries and major agricultural cover types were identified through visual inspection using ARC GIS 10.1, ERDAS IMAGINE software, and reference to 543 geocoded control points of land cover taken in the study area in April 2012. Fieldwork notes included observations on the functioning of vegetative cover in between-field and irrigationcanal environments, i.e., effectively comprising "matrix" among the patches of agricultural fields. Detailed surveys of land use and livelihoods were conducted in the study areas between 2006 and 2012 using a structured random design $(n=174$ households, 347 fields). Questions in this survey included characteristics of maize fields; general maize-growing functions; social-ecological interactions within the cultural landscape, i.e., cultivation including inputs such as land and labor, resource use and organization, landrace types, and food properties along with other uses of harvest; and livelihood activities, i.e., on- and off-farm work activities, such as migration and related use of social networks.

\section{RESULTS}

The Tarata-Arbieto cultural landscape is home to $\sim 2500$ persons and is composed of numerous features and processes related to maize landrace diversity, ecosystem services, global change, and intensification of food production (Table 2). Small- to mediumsize villages, many located along major irrigation canals at a distance of $2.5-4.5 \mathrm{~km}$ from principal off-takes (Fig. 3), provide access to a large number of fields $(n=7922)$ in this cultural landscape. Smallholding households typically access up to 5 scattered agricultural fields, with maize growing predominant (Table 3; 2382 fields total, or $30.0 \%$ of classified agricultural plots), followed by wheat, peach, fallow plowed fields, and alfalfa. Irrigation is extensive, utilized in $81 \%$ of maize fields. Irrigated maize growing has characterized this cultural landscape since the 1500s (Larson 1988) and presumably for at least 1200 years (Zimmerer 1995). Maize growing is also common in rain-fed fields. Moisture-conserving techniques such as dry-farming tillage (Table 2) are widespread. Sampled maize fields $(n=256)$ consisted entirely of landraces. Reasons for the absence of "improved varieties" included perceived lack of suitable choices $(92 \%)$ and strong preference for the consumption and fodder qualities of landraces $(71 \%)$.

The predominance of maize growing is driven through various factors in the Tarata-Arbieto cultural landscape. Significant ranges of both maturation periods and culinary categories were characteristic of the 10 distinct types of maize landraces cultivated and consumed (Table 4). Phenologic variation of this 
Fig. 4. Diagram of the variation of maturation traits, i.e., phenology, and consumption uses of maize landraces.

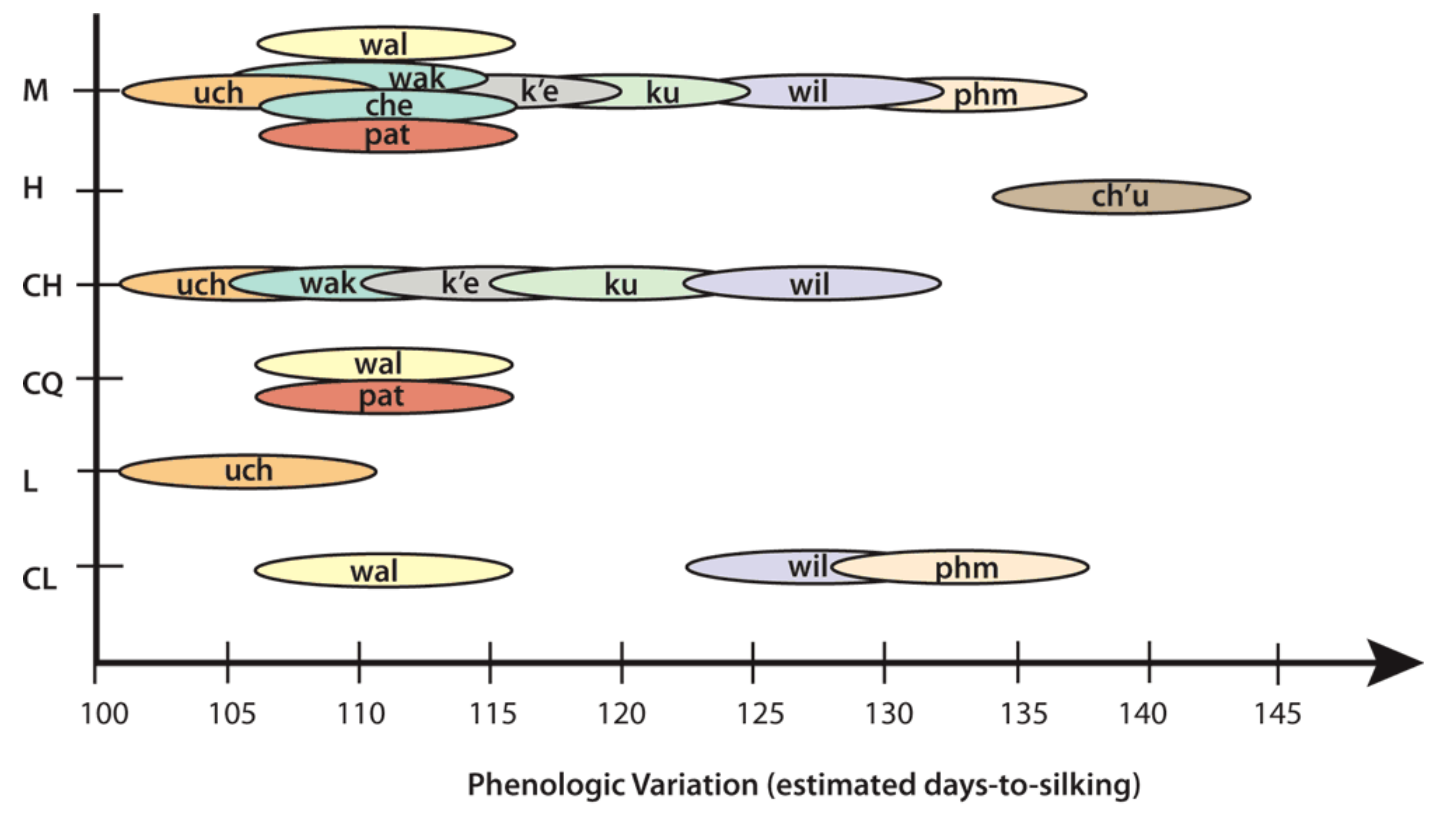

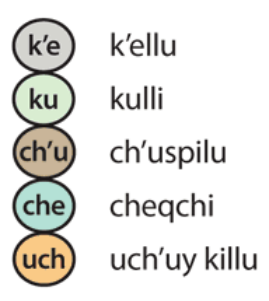

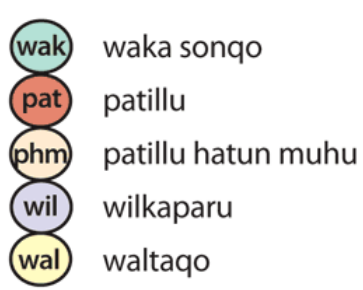

group comprises a range of short-, medium-, and long-cycle types, widely recognized among maize growers, and provides choices of diverse maturation periods that enable fast-maturing landraces for rain-fed areas and sites with uncertain irrigation availability and slow-maturing, long-cycle landraces well suited to reliably irrigated parcels. Maturation-based, landrace-level phenologic variation is crucial in lessening the risk of crop loss attributable to climate fluctuations and, in particular, reduced growing seasons, drought, and shortages of soil moisture. This function of phenologic variation is suited to the soil-moisture variation of fields across the cultural landscape (Zimmerer 2011). Also, because many growers typically plant multiple fields with maize, i.e., approximately $47 \%$ sowed 2 or more maize fields, phenologic variation enables these smallholder growers to reduce landscapelevel cropping risk resulting from water shortfalls. Detailed geospatial analysis did not show, however, the occurrence of patterning in relation to irrigation. In these results, GIS techniques were used to test whether the locations of specific landraces, and hence maturation periods, were related to field distance from irrigation canal, i.e., the "water-gradient hypothesis" of short-cycle types planted in tail-end fields. Statistically significant relations were not detected ( $n=254$ fields). One factor observed as influential is the evident complex waterdelivery functioning of local irrigation that imposes irregular spatial impacts, rather than regular distance-decay effects.
Significant variation of consumption uses through culinary preparations of locally common foods and beverages is similarly critical to the number of diverse maize landraces in the TarataArbieto cultural landscape (Table 4). Principal consumption uses are hominy (mote), toasting (hank'a), and production of a fermented "maize beer" (chicha). Widespread secondary uses include corn-on-the-cob (choqllo), soup thickener (lawa), and common maize-based beverages, e.g., api. Each type of landrace supplies certain principal culinary preparations so that the variation and range of consumption uses exerts a strong, positive influence on agrobiodiversity. The conjoined variation of phenologic and consumption-use parameters results in combined selection pressures and preferences propelling the suite of local maize landraces (Fig. 4). Some overlap of these paired traits also suggests the possibility of redundancy that is characteristic of many biodiversity-rich ecosystems (Tscharntke et al. 2005). In sum, this collective diversity of landraces helps both to provide preferred food types of food and reduce the risk of maize growing in the Tarata-Arbieto cultural landscape.

Maize-producing households in this landscape carried out 8.5 major livelihood activities, on average, between 2006 and 2012 (Table 5). These diverse livelihood portfolios reflected the periurban location and included the local manufacture and vending of maize beer (chicha); peach growing and sales; legume and wheat 
Table 2. Features of cultural landscape supporting maize landrace diversity in Andean valleys: example of Tarata-Arbieto, Bolivia.

\begin{tabular}{|c|c|c|c|}
\hline $\begin{array}{l}\text { Cultural Landscape Features } \\
\text { and Processes }\end{array}$ & $\begin{array}{l}\text { Relation(s) to Maize } \\
\text { Cultivation and Landrace } \\
\text { Diversity }\end{array}$ & $\begin{array}{l}\text { Observed Ecosystem Services in Cultural } \\
\text { Landscape }\end{array}$ & $\begin{array}{l}\text { Active Migration-related } \\
\text { Group(s) in Cultural } \\
\text { Landscape }\end{array}$ \\
\hline $\begin{array}{l}\text { Dispersed villages with } \\
\text { smallholder farming and field } \\
\text { size }\end{array}$ & $\begin{array}{l}\text { Widespread access of a large } \\
\text { number of farmers to many } \\
\text { separate planting sites }\end{array}$ & $\begin{array}{l}\text { Extensive areas of field borders, } \\
\text { including hedgerows of shrub vegetation, } \\
\text { providing habitat to wildlife (e.g., birds), } \\
\text { and beneficial insects }\end{array}$ & $\begin{array}{l}\text { All groups (owners, } \\
\text { migrants, field- } \\
\text { caretakers, in-migrant } \\
\text { field laborers) }\end{array}$ \\
\hline $\begin{array}{l}\text { Extensive irrigation canals } \\
\text { and associated canal habitats } \\
\text { (e.g., woodlands) }\end{array}$ & $\begin{array}{l}\text { Irrigation enables the wide } \\
\text { variety of growing seasons } \\
\text { for maize cultivation }\end{array}$ & $\begin{array}{l}\text { Extensive areas along earth-lined canals } \\
\text { of riparian-type habitats including tree } \\
\text { cover and wildlife }\end{array}$ & $\begin{array}{l}\text { All groups (owners, } \\
\text { migrants, field- } \\
\text { caretakers, in-migrant } \\
\text { field laborers) }\end{array}$ \\
\hline Moisture-conserving tillage & $\begin{array}{l}\text { Contributes to viability of } \\
\text { extensive cultivation of } \\
\text { maize, including rain-fed } \\
\text { production (especially short- } \\
\text { cycle varieties) }\end{array}$ & $\begin{array}{l}\text { Conservation of water resources and } \\
\text { moisture in soil habitats; compatible with } \\
\text { establishment of ground cover, including } \\
\text { native forage plants }\end{array}$ & $\begin{array}{l}\text { All groups (owners, } \\
\text { migrants, field- } \\
\text { caretakers, in-migrant } \\
\text { field laborers) }\end{array}$ \\
\hline $\begin{array}{l}\text { Knowledge-based system of } \\
\text { maize landrace diversity } \\
\text { stipulated through diverse } \\
\text { food preferences and uses }\end{array}$ & $\begin{array}{l}\text { Motivates extensive } \\
\text { cultivation of diverse maize } \\
\text { landraces grown for a variety } \\
\text { staple food uses }\end{array}$ & $\begin{array}{l}\text { Direct: food production and food } \\
\text { security } \\
\text { Indirect: as principal motivator for } \\
\text { cultural landscape of smallholder } \\
\text { production, irrigation, moisture- } \\
\text { conserving tillage, and staggered growing } \\
\text { season }\end{array}$ & $\begin{array}{l}\text { All groups (owners, } \\
\text { migrants, field- } \\
\text { caretakers, in-migrant } \\
\text { field laborers) }\end{array}$ \\
\hline $\begin{array}{l}\text { Knowledge-based system of } \\
\text { maize landrace diversity } \\
\text { stipulated through irrigated- } \\
\text { based staggered planting and } \\
\text { growing seasons }\end{array}$ & $\begin{array}{l}\text { Motivates cultivation of } \\
\text { diverse maize landraces with } \\
\text { phenologic variation of } \\
\text { maturation period }\end{array}$ & $\begin{array}{l}\text { Conservation of water resources and } \\
\text { moisture in soil habitats }\end{array}$ & $\begin{array}{l}\text { All groups (owners, } \\
\text { migrants, field- } \\
\text { caretakers, in-migrant } \\
\text { field laborers) }\end{array}$ \\
\hline
\end{tabular}

cropping; potato agriculture; alfalfa production and small dairy herds; cheese making; other livestock raising, e.g., sheep and goats; storekeeping; taxi service; local labor in villages of the study area; regional and national migration within Bolivia; international migration to Argentina; and international migration to the United States, Spain, and other countries outside South America. A majority of surveyed households $(89 \%)$ contained 1 or more members who had migrated internationally. Most migrants were able to coordinate their varied livelihood activities with continued knowledge of the uses of maize landraces. For example, migrants and nonmigrants were estimated to hold similar levels of general knowledge that differed insignificantly with regard to the maturation-based variation of landraces (chi-square $=1.01, \mathrm{df}=2, P=0.604$ ) and landrace suitability for consumption usages (chi-square $=0.110, \mathrm{df}=2, P$ $=0.946)$.

Livelihood changes, as well as certain continuities, have been characteristic of the recent farming of maize landraces within the Tarata-Arbieto cultural landscape. In particular, growers increasingly comprised larger shares of women and in-migrant laborers, with continuation of village and smallholding land systems; some irrigation canals became concrete-lined, with continuation of canal-side habitats; and tractors became more common, with continuation of moisture-conserving tillage. Parttime farmers thus managed to respond to global socioeconomic changes through adopting innovations and the associated livelihood activities that enabled the continued integration of maize landrace growing into the changing cultural landscape (Table 2).

Distinct roles of diverse livelihood groups and the social networks among them have emerged as increasingly central to Andean maize growing, use, and in situ conservation amid the livelihood transitions described previously (Fig. 5). First, women farmers, consumers, and local business owners have exerted considerable demand for specific maize landraces and thus have helped enable overall landrace diversity amid changes in the Tarata-Arbieto cultural landscape. Second, the role of migrants has influenced land-use decision making and cultural landscapes, including Andean maize growing and use, even though they reside principally in other places. Third is a relatively new group of field caretakers, known as encargados, who are designated to undertake farm-management responsibilities, including the field-level production of maize landraces. These field caretakers have become widely utilized among migrant households. Fourth is still another new group composed of poorer in-migrant laborers from the nearby highlands whose inexpensive labor has also enabled continuation of maize growing as well as other activities related to ecosystem processes, e.g., maintenance of irrigation canals that influence soil moisture in the cultural landscape. 
Table 3. Estimated overall areas and the numbers and sizes of individual fields of the major types of cover in agriculture of the TarataArbieto cultural landscape.

\begin{tabular}{|c|c|c|c|c|c|c|}
\hline Cover Type & Area Fields (ha) & Percent & Number Fields & Percent & $\begin{array}{c}\text { Mean Field } \\
\text { Size (ha) }\end{array}$ & $\begin{array}{l}\text { Standard } \\
\text { Deviation }\end{array}$ \\
\hline Maize & 5338 & 30.3 & 2382 & 30.0 & 0.23 & 0.164 \\
\hline Peach & 2123 & 12.0 & 825 & 10.4 & 0.27 & 0.219 \\
\hline Wheat & 2689 & 14.9 & 704 & 8.9 & 0.43 & 0.443 \\
\hline Alfalfa & 1000 & 5.1 & 621 & 7.8 & 0.17 & 0.105 \\
\hline Fallow & 1945 & 10.7 & 879 & 11.1 & 0.22 & 0.184 \\
\hline Plowed & 1189 & 6.7 & 490 & 6.2 & 0.25 & 0.222 \\
\hline $\begin{array}{l}\text { Other Crops and } \\
\text { Unknowns }\end{array}$ & 3560 & 20.3 & 2021 & 25.5 & 0.18 & 0.153 \\
\hline Total & 17,856 & & 7922 & & & \\
\hline
\end{tabular}

Other Crops $=$ Potatoes, Peas, Fava, Quinoa, and Minor Crops

Fig. 5. Interconnections of migration-related livelihood groups in agrobiodiversity resilience and conservation.

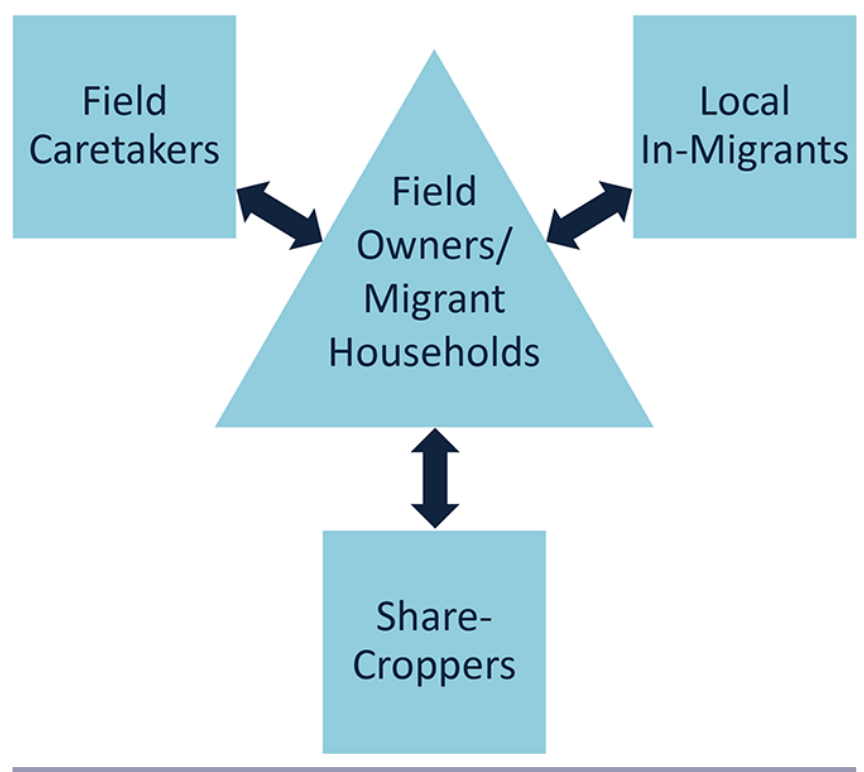

Interconnections of the roles of each of the livelihood groups mentioned previously, and illustrated by two-way arrows in Figure 5 , are integral to the production and use of maize landrace agrobiodiversity as well as specific functions, e.g., irrigation and tillage, in this cultural landscape. Social networks are reflected in the linkages among these groups. Women farmers, for example, have become responsible for overseeing the production of approximately one-half of surveyed maize fields (49\%). Typically, these women are members of households where men, often their husbands, have migrated and are working elsewhere for extended periods. Recently, women also have migrated more frequently. As a result, households of multiple migrants have often shifted to reliance on field caretakers. Survey results showed that $31 \%$ of all maize fields were being overseen by persons acting in this role. In general, such persons are chosen from networks of other family members; close friends, also known as "social kin"; and neighbors.

Both women and caretakers overseeing maize production commonly make use also of their social networks of contracted in-migrants who are poorer rural laborers from the nearby highlands. Survey findings demonstrated that more than one-half of all maize fields $(52 \%)$ relied on the work inputs of these laborers. Testing showed that the active roles of women, field caretakers, and in-migrant laborers were not restricted or significantly more common in any one of the principal phenologybased plantings, i.e., long-, medium-, and short-season maturation periods (chi-square $=2.00, \mathrm{df}=6, P=0.919$ ). Similarly, the work activities of these groups, i.e., women, field caretakers, and in-migrant laborers, were not associated with the production of specific types of maize landraces. In sum, the dynamic roles among different migrant-related groups are not significantly differentiated with regard to the production of diverse maize landraces within the cultural landscape. At the same time, their increased contributions and networked connections have been guided by major global changes because labor migration is an important form of socioeconomic globalization.

Continuation of the knowledge and use of maize landrace diversity in conjunction with the associated Tarata-Arbieto cultural landscape, e.g., irrigation, field-side habitats, and tillage, has contributed positively to the social-ecological resilience. Social-ecological resilience refers in this research to the capacity of maize-growing households to continue to cultivate landrace diversity amid climatic variation and possible climate change impacts, for example, drought, and global socioeconomic integration, e.g., migration. Both phenologic variation and valued food uses of landrace-level maize agrobiodiversity, in other words combined production and consumption functions, help enable response capacity to these social-ecological changes. Seen as stressors and disturbances from an ecological perspective (Turner 2013), these factors also resemble, to a certain extent, pre-existing conditions in this landscape (Larson 1988, Zimmerer 1995). Intensified occurrences presently pose significant challenges to social-ecological resilience in general and specifically that of agrobiodiversity and its supporting cultural landscapes. To date, the valued usages of phenologic variation and food preparations 
Table 4. The phenologic variation of maturation period and the principal consumption uses of maize landraces.

\begin{tabular}{|c|c|c|c|c|}
\hline & $\begin{array}{l}\text { Taxonomic } \\
\text { Race }\end{array}$ & $\begin{array}{c}\text { Phenology (average } \\
\text { days-to-silking) }\end{array}$ & $\begin{array}{c}\text { Cultural Phenologic } \\
\text { Group }\end{array}$ & Principal Consumption Uses \\
\hline k'ellu & Kcellu & 115 & $\mathrm{CM}$ & $\mathrm{M}, \mathrm{CH}$ \\
\hline kulli & Kulli & 120 & $\mathrm{CM}$ & $\mathrm{CH}, \mathrm{M}$ \\
\hline ch'uspillu & Chuspillo & 139 & $\mathrm{HM}$ & $\mathrm{H}$ \\
\hline cheqchi & Checchi & 111 & $\mathrm{CM}$ & M \\
\hline uch'uy killu & Uchuquilla & 106 & UM & $\mathrm{M}, \mathrm{CH}, \mathrm{L}$ \\
\hline Waka sonqo & Huaca Sonqo & 110 & $\mathrm{CM}$ & $\mathrm{M}, \mathrm{CH}$ \\
\hline patillu & Patillo & 111 & $\mathrm{CM}$ & $\mathrm{M}, \mathrm{CQ}$ \\
\hline Patillu hatun muhu & Patillo Grande & 133 & HM & $\mathrm{M}, \mathrm{CL}$ \\
\hline wilkaparu & Huillcaparu & 127 & $\mathrm{HM}$ & $\mathrm{M}, \mathrm{CH}, \mathrm{CL}$ \\
\hline waltaqo & Hualtaco & 111 & $\mathrm{CM}$ & $\mathrm{CQ}, \mathrm{M}, \mathrm{CL}$ \\
\hline
\end{tabular}

Cultural Phenologic Group: HM = hatun muhu ("big seed"); CM = chawpi muhu ("medium seed"); UM = uch'uy muhu ("small seed")

Principal Consumption Uses: $\mathrm{M}=$ mote (hominy); $\mathrm{CH}=$ chicha (fermented beverage); $\mathrm{H}=$ hank'a (parched); $\mathrm{CQ}=$ choqllo (cornon-the-cob); $\mathrm{L}=$ lawa (soup thickener); $\mathrm{CL}=$ challa (forage)

reveal how social-ecological resilience can be built on strong landscape and livelihood preferences. Still this social-ecological resilience does not indicate an absence of problems; deterioration of soil and water quality that undermines adequate management, for example, has mounted in recent decades (Shriar 2010, Zimmerer 2010b, 2011). Such problems suggest that possible declines in conditions of the cultural landscape providing ecosystem services must become significant, integral elements of the analysis of landrace-level agrobiodiversity.

\section{DISCUSSION: MANAGEMENT AND POLICY OPTIONS FOR RESILIENCE AND CONSERVATION}

My findings provide a new perspective on the cultural landscapes of agrobiodiversity amid dynamic livelihood transitions in a global hot spot. These results focus on the planned biodiversity of landraces, while they also pertain to various elements of the associated biodiversity. Analysis shows that in situ conservation, use, and ecosystem services associated with a cultural landscape co-occur with the combined production and consumption of diverse landraces. During recent decades, agrobiodiversityproducing cultural landscapes have been increasingly interacting with livelihood shifts that include significant "nontraditional" transitions and trends, particularly migration, peri-urbanization, and issues of social justice. My research findings are directed to discussion and analysis of a series of new management and policy options for sustainability and the in situ conservation of agrobiodiversity. The goal is to contribute to novel initiatives while enhancing the social-ecological resilience of Andean maize growers and their landrace diversity and cultural landscapes. Both potential contributions and limitations of migration-related roles are elucidated.

Landrace diversity is seen as a key to social-ecological resilience involving food security, access, and quality (Wood and Ehui 2005, Hajjar et al. 2008, Jarvis et al. 2008, Lobell and Burke 2010, Ericksen et al. 2010, Chateil et al. 2013). Landrace diversity can aid the capacity for this resilience in the context of global environmental and socioeconomic changes that include climate and development shocks. Maturation-based phenologic variation, for example, is vitally important in adaptations to climatic variation and change. Findings highlight that the activities of women, as combined (nonseparable) consumers, producers, and business owners; migrants; field caretakers; and in-migrant laborers have become increasingly pivotal to enabling the overall viability and ensuring future prospects of diverse maize landraces. The intersecting relations in this network reinforce my concept of cultural landscapes as bridging multiple livelihood groups, scales, sites, and time periods.

My findings are consistent with the expanded recognition and growing use of management and policy approaches to the in situ conservation and potential ecosystem services of traditional crop varieties (Jarvis et al. 2011, Zimmerer 2012). This also highlights the vital importance of expanding this analysis of landrace-level agrobiodiversity into new types of livelihood and development contexts, such as peri-urban locales. The perspective of cultural landscapes is important for understanding landrace-specific food preferences extending to off-farm consumers who acquire maize in local and regional marketplaces, while processor specifications are especially influential in the demand for diverse maize landraces as chief ingredients of the popular maize beverage known as chicha. Findings emphasize that market integration does not necessarily diminish the relation of knowledge to crop diversity in complex indigenous societies (see also Reyes-García et al. 2007).

Women comprise the large majority of persons providing the labor and knowledge for the use of diverse maize landraces (see also Jewitt 2002, Oakley and Momsen 2005, Carney 2007, Chambers and Momsen 2007, Zimmerer 2011). Local women's organizations, such as those intended to promote food security, business development, and family well-being, are promising avenues for management and policy options in support of in situ conservation. The benefits of women's multifaceted roles, as sketched previously, will need to be incorporated into suitably versatile and expansive concepts of the cultural landscapes of 
Table 5. Livelihood characteristics of migrants, field caretakers, and in-migrant laborers.

\begin{tabular}{|c|c|c|}
\hline & Statistical Estimate & $\begin{array}{l}\text { Standard } \\
\text { Deviation }\end{array}$ \\
\hline Mean number of major livelihood activities per household $(n=174)$ & 8.5 & 4.9 \\
\hline $\begin{array}{l}\text { Mean number of international migration events }(2006-2010) \text { among migrant } \\
\text { households }(\mathrm{n}=111)\end{array}$ & 1.8 & 0.9 \\
\hline Mean number of migration-years within household (2006-2010) & 3.7 & 2.2 \\
\hline Estimated investment of remittances in agriculture (2009) & US\$145 & US\$83 \\
\hline Percent with Argentina as earliest migration destination & $85 \%$ & \\
\hline Percent migrants with U.S. or Spain as most recent destination & $78 \%$ & \\
\hline Percent woman-headed agricultural households & $67 \%$ & \\
\hline $\begin{array}{l}\text { Percent households employed field caretakers (encargados) in the 2006-2010 } \\
\text { period }\end{array}$ & $32 \%$ & \\
\hline $\begin{array}{l}\text { Percent field caretaker arrangement involves households with international } \\
\text { migration }\end{array}$ & $78 \%$ & \\
\hline Percent households employed in-migrant workers (Latinos) in 2009 & $42 \%$ & \\
\hline
\end{tabular}

agrobiodiversity. To enable such options will require that cultural landscapes be seen as comprising both conventional cultivation sites and prospective linkages to ecosystem services and the spaces and processes of food consumption, culinary preparation, processing, marketing, and seed exchange.

Results of migration analysis lead to insights for agrobiodiversity management and policy options incorporating positive relations to land use, labor provisioning, remittance usage, and, more generally, social-ecological resilience (Adger et al. 2002, Berkes and Turner 2006). The options related to migration must recognize significant agrobiodiversity peri-urbanization and interactions with nonlocal, nontraditional, and migration factors providing noteworthy opportunities. Specific influences of migration on cultural landscapes and agrobiodiversity in Bolivia's High Valley underscores the versatility of livelihood choices, financial resources, educational background, and dense social networks that include migrants' civic organizations. This suite of migration-related activities and institutions may be especially suitable for initiatives incentivizing maize agrobiodiversity and its cultural landscapes along with potential ecosystem services. For example, migrants frequently recount acquisitions of favored maize foodstuffs while living in faraway places, suggesting potential entrepreneurship-based options. High Valley migrants in the United States, i.e., about 60,000 Bolivians, mostly from the High Valley, who live in the Washington, D.C., area (Yarnall and Price 2010), place a premium value on the eating qualities of toasted Andean maize and equal or higher importance on fermented chicha. These culinary preferences across multisite and multiscale cultural landscapes could be used to support specialty market outlets as well as food-security programs.

Field caretakers, or encargados, are another social category that is both "nontraditional" and increasingly indispensable to the cultural landscape of agrobiodiversity use and in situ conservation. At the same time, field caretakers tend to receive little recognition either inside or outside this cultural landscape because as nonowners they are marginalized in both official and informal accounting of land use and agriculture. My findings urge that the roles of field caretakers and other nonowners must be recognized to design and pursue effective practicable designs for agrobiodiversity and sustainability. The capacity of field caretakers to contribute to management and policy options related to sustainability will depend on strong local institutions and community user-group organizations. My findings recommend that the region's irrigator group, i.e., the Laka Laka Irrigators' Association (ARLL), is well suited to agrobiodiversity initiatives because it increasingly commits to water-conserving approaches and food-security goals. ARLL and other institutions are increasingly aware of strong positive feedbacks between the quality of soil and water resources and the viability of Andean maize agrobiodiversity. At the same time, the ARLL is in need of governance reforms to better enable the fuller levels of participation and empowerment needed for expanding social groups such as field caretakers.

In-migrants similarly have become integral to the positive benefitcost ratios perceived as part of in situ conservation in new cultural landscapes (see also Smale 2005). However, in-migrant workers are a mostly invisible social category with higher levels of poverty and lack of resources leading to their vulnerability to food shortages and to declining conditions of their home communities. Their involvement in maize-landrace growing and use is integral to the cultural landscape of diverse maize and in situ conservation in the High Valley. Social justice initiatives as well as high-visibility heritage food fairs such as the successful local event known as Nawpaq Miqhuna ("Ancient Foods"), benefiting more well-todo venders (Albro 2009), will need to be expanded with alternatives designed to support the food-security and well-being needs of the in-migrants whose work activities enable the cultural landscape of diverse maize landraces. This social justice insight underscores the important if ironic perspective that nontraditional livelihoods are now increasingly integral to Ancient Foods in particular as well as agrobiodiversity in general.

\section{CONCLUSION: LINKING AGROBIODIVERSITY, CULTURAL LANDSCAPES, AND NONTRADITIONAL LIVELIHOOD ACTIVITIES AND SOCIAL NETWORKS}

Landraces of major food plants, such as maize, provide agroecological and consumption resources within cultural landscapes that can support social-ecological resilience, in situ conservation, and ecosystem services. Locally widespread use of 
landraces highlights the vital roles of maturation-based phenologic variation in response to soil-moisture variation, stemming from irrigation and climate factors; variation of landrace-related food types, influencing food security; and active conservation of genetic resources in the context of a dynamic cultural landscape. Sustainability policy and management aimed at landrace-level agrobiodiversity must be enabled through the integrative analysis of cultural landscapes. The latter encompasses the activities and concerns of land use and nutritional quality as well as surrounding habitats and socialecological processes, e.g., irrigation and canal-side habitats and uncultivated field boundaries, also integral to agrobiodiversity. Knowledge and use of the twin combination of maturationperiod traits, i.e., phenology, and culinary suitability are closely related cornerstones of maize landrace agrobiodiversity. Management of the significant variation along these twin dimensions representing both production and consumption is crucial to understanding the future viability of highagrobiodiversity Andean maize growing. Present-day use and historical development of the High Valley's cultural landscape would be unlikely if not for these twin factors, i.e., prominence and desirability of growing-season and culinary variants.

The concept of cultural landscape applied to the use of agrobiodiversity indicates the need to incorporate nontraditional livelihood factors. In particular, the cultural landscape of agrobiodiversity shows potential compatibility with the expansion of non- and off-farm livelihood activities. Nontraditional livelihoods can therefore function as integral counterparts to the in situ conservation and sustainability of agrobiodiversity in the study context. Analysis concludes that the activities of four significant livelihood groups and their social networks, i.e., women as producer-consumers, farmers, and processors; migrants; field caretakers; and in-migrant laborers, are powerfully shaped through international and national migration while at the same time supporting agrobiodiversity use and in situ conservation. The global transitions evident in pronounced livelihood diversification and new social networks denotes the continuation, albeit with significant change, of the agrobiodiversity-supporting cultural landscape of Bolivia's High Valley.

Finally, my analysis offers new insights regarding the importance of social inclusion, participation, planning, and empowerment activities of specific groups that must be priorities in the delimitation, design, and deployment of agrobiodiversity management options and policy. These conclusions for management and policy urge the use of the cultural landscapes framework to guide agrobiodiversity assessment, monitoring, and support to strengthen social-ecological resilience amid powerful global changes. Integrative approaches based on the concept of cultural landscapes must account for the increasingly influential interactions of agrobiodiversity with nontraditional livelihood activities and emerging livelihood groups. The fate of agrobiodiversity, in particular in situ conservation outcomes, will be increasingly determined through migration activities that include the important roles of new and diverse migration-related processes, groups, and their knowledge systems and social networks located across diverse sites.
Responses to this article can be read online at: http://www.ecologyandsociety.org/issues/responses. $\mathrm{php} / 6316$

\section{Acknowledgments:}

My knowledge of maize agrobiodiversity used in this research traced a migratory route from $H$. and I. Baker at University of California, Berkeley, and I. Budenhagen at University of California, Davis, to M. Goodman, C. Stuber, and R. Bird in North Carolina, H. Iltis and J. Doebly at University of Wisconsin-Madison, and J. Lynch at Penn State, along with R. Sevilla and C. Fonseca in Peru and G. Avila in Bolivia. My work and collaborations with agrobiodiversity, community, agrobiodiversity, and alternative development groups and research institutions include AGRUCO, ARLL, CESU, and PROINPA (Bolivia); UNALM, CIP, and CONDESAN (Peru); CIAT (Colombia); CIMMYT (Mexico); and Escuela Bolivia in Arlington, Virginia. Individual collaborators included N. Tapia, F. Delgado, S. Rist, M. Bell, D. Retchless, Q. Di, L. Schneider, L. Rojas, T. Hosse, B. Moats, J. Centellas, A. Cáceres, M. Ebersole, B. Barham, D. Lewis, D. Praeger, E. Carter, J. Burt, A. Burnicki, A. Ruane, R. Hedberg, and Z. Browne. Research in phase I (2002-2006) and phase II (2007-2013) was funded through NSF BC 0240962 (University of Wisconsin-Madison) and NSF HSD 0948816 (Penn State). B. L. Turner II, A. Lerner, E. Lambin, R. DeFries, and $K$. McSweeney provided helpful feedback on presentations of this work. Traditional/nontraditional hybrids were a major emphasis of my research and teaching at Yale (2004-2005), benefiting from interactions with $M$. Dove, C. Carpenter, J. Scott, E. Mayer, and W. Wolford. Institutional collaborators included Penn State's Colleges of Agricultural Sciences and EMS, with the latter's Dean Bill Easterling providing exceptional support of new approaches to global change research. Special thanks go to the issue editors and colleagues currently working on the themes of agrobiodiversity and cultural landscapes.

\section{LITERATURE CITED}

Adger, W. N., P. M. Kelly, A. Winkels, L. Q. Huy, and C. Locke. 2002. Migration, remittances, livelihood trajectories, and social resilience. AMBIO: A Journal of the Human Environment 31:358-366.

Albro, R. 2009. Neoliberal cultural heritage and Bolivia's new indigenous public. Pages 146-161 in C. Greenhouse, editor. Ethnographies of neoliberalism. University of Pennsylvania Press, Philadelphia, Pennsylvania, USA.

Altieri, M. A. 1999. The ecological role of biodiversity in agroecosystems. Agriculture, Ecosystems \& Environment 74 (1-3):19-31. http://dx.doi.org/10.1016/S0167-8809(99)00028-6

Ávila, G. A., L. Guzman, and M. Céspedes. 1998. Catálogo de Recursos Genéticos de Maíces Bolivianos. Centro de Investigaciones Fítogenéticos de Pairumani, Cochabamba, Bolivia.

Batterbury, S. 2001. Landscapes of diversity: a local political ecology of livelihood diversification in south-western Niger. Cultural Geographies 8:437-464. http://dx.doi.org/10.1177/096746080100800404 
Bebbington, A. 2001. Globalized Andes? Livelihoods, landscapes and development. Cultural Geographies 8:414-436. http://dx.doi. org/10.1177/096746080100800403

Bellon, M. R., D. Hodson, and J. Hellin. 2011. Assessing the vulnerability of traditional maize seed systems in Mexico to climate change. Proceedings of the National Academy of Sciences of the United States of America 108(33):13432-13437. http://dx. doi.org/10.1073/pnas.1103373108

Berkes, F., and N. J. Turner. 2006. Knowledge, learning and the evolution of conservation practice for social-ecological system resilience. Human Ecology 34:479-494. http://dx.doi.org/10.1007/ s10745-006-9008-2

Beymer-Farris, B. A., T. J. Bassett, and I. Bryceson. 2012. Promises and pitfalls of adaptive management in resilience thinking: the lens of political ecology. Pages 283-299 in T. Plieninger and C. Bieling, editors. Resilience and the cultural landscape: understanding and managing change in human-shaped environments. Cambridge University Press, New York, New York, USA. http://dx.doi.org/10.1017/CBO9781139107778.020

Bianchi, F. J. J. A., V. Mikos, L. Brussaard, B. Delbaere, and M. M. Pulleman. 2013. Opportunities and limitations for functional agrobiodiversity in the European context. Environmental Science \& Policy 27:223-231. http://dx.doi.org/10.1016/j.envsci.2012.12.014

Birkenholtz, T. 2009. Irrigated landscapes, produced scarcity, and adaptive social institutions in Rajasthan, India. Annals of the Association of American Geographers 99:118-137. http://dx.doi. org/10.1080/00045600802459093

Brandolini, A. 1970. Maize. Pages 273-309 in O. H. Frankel and E. Bennett, editors. Genetic resources in plants - their exploration and conservation. F. A. Davis, Philadelphia, Pennsylvania, USA.

Brosius, J. P. 2006. What counts as local knowledge in global environmental assessments and conventions? Pages 129-144 in W. V. Reid, F. Berkes, T. Wilbanks, and D. Capistrano, editors. Bridging scales and knowledge systems: concepts and applications in ecosystem assessment. Island, Washington, D.C., USA.

Brush, S. B. 2004. Farmers' bounty: locating crop diversity in the contemporary world. Yale University Press, New Haven, Connecticut, USA. http://dx.doi.org/10.12987/yale/9780300100$\underline{495.001 .0001}$

Brush, S. B., and H. R. Perales. 2007. A maize landscape: ethnicity and agro-biodiversity in Chiapas Mexico. Agriculture, Ecosystems \& Environment 121:211-221. http://dx.doi.org/10.1016/j.agee.2006.12.018

Calvet-Mir, L., M. Calvet-Mir, J. Luis Molina, and V. ReyesGarcía. 2012. Seed exchange as an agrobiodiversity conservation mechanism. A case study in Vall Fosca, Catalan Pyrenees, Iberian Peninsula. Ecology and Society 17(1): 29. http://dx.doi. org/10.5751/ES-04682-170129

Calvo-Iglesias, M. S., R. Crecente-Maseda, and U. Fra-Paleo. 2006. Exploring farmer's knowledge as a source of information on past and present cultural landscapes: a case study from NW Spain. Landscape and Urban Planning 78:334-343. http://dx.doi. org/10.1016/j.landurbplan.2005.11.003

Carney, J. A. 2003. Agroenvironments and slave strategies in the diffusion of rice culture to the Americas. Pages 256-273 in K. S. Zimmerer and T. J. Bassett, editors. Political ecology: an integrative approach to geography and environment-development studies. Guilford, New York, New York, USA.

Carney, J. A. 2007. 'Asleep then but awake now': contesting irrigated land along the Gambia River. Pages 169-187 in A. Baviskar, editor. Waterscapes: the cultural politics of a natural resource. Permanent Black, Uttaranchal, India.

Cash, D. W., W. Adger, F. Berkes, P. Garden, L. Lebel, P. Olsson, L. Pritchard, and O. Young. 2006. Scale and cross-scale dynamics: governance and information in a multilevel world. Ecology and Society 11(2): 8. [online] URL: http://www.ecologyandsociety. org/vol11/iss2/art8/

Cassman, K. G., and S. Wood. 2005. Cultivated systems. Pages 745-794 in R. Hassan, R. Scholes, and A. Neville, editors. Ecosystems and human well-being: current states and trends, volume 1. The Millennium Ecosystem Assessment Series, Island, Washington, D.C., USA.

Chambers, K. J., and J. H. Momsen. 2007. From the kitchen and the field: gender and maize diversity in the Bajio region of Mexico. Singapore Journal of Tropical Geography 28:39-56. http://dx.doi. org/10.1111/j.1467-9493.2006.00275.x

Chateil, C., I. Goldringer, L. Tarallo, C. Kerbiriou, I. Le Viol, J.F. Ponge, S. Salmon, S. Gachet, and E. Porcher. 2013. Crop genetic diversity benefits farmland biodiversity in cultivated fields. Agriculture, Ecosystems \& Environment 171:25-32. http://dx.doi. org/10.1016/j.agee.2013.03.004

Convention on Biological Diversity (CBD). 2013a. COP 5 decision V/5. Agricultural biological diversity. CBD, Montreal, Quebec, Canada. [online] URL: www.cbd.int/decision/cop/ default.shtml

Convention on Biological Diversity (CBD). 2013b. What is agricultural biodiversity? CBD, Montreal, Quebec, Canada. [online] URL: www.cbd.int/agro/whatis.shtml

Coomes, O. T., and N. Ban. 2004. Cultivated plant species diversity in home gardens of an Amazonian peasant village in northeastern Peru. Economic Botany 58:420-434.

Council of Europe. 2000. European landscape convention (adopted on 20 October 2000 in Florence, Italy). Council of Europe Treaty Series No. 176, Council of Europe, Strasbourg, France. [online] URL: http://conventions.coe.int/Treaty/en/Treaties/Html/176.htm

de Haan, S., J. Núñez, M. Bonierbale, and M. Ghislain. 2010. Multilevel agrobiodiversity and conservation of Andean potatoes in central Peru: species, morphological, genetic, and spatial diversity. Mountain Research and Development 30(3):222-231. http://dx.doi.org/10.1659/MRD-JOURNAL-D-10-00020.1

Ericksen, P., B. Stewart, J. Dixon, D. Barling, P. Loring, M. Anderson, and J. Ingram. 2010. The value of a food system approach. Pages 25-45 in J. Ingram, P. Ericksen, and D. Liverman, editors. Food security and global environmental change. Earthscan, London, UK.

Erickson, C. L. 2003. Agricultural landscapes as world heritage: raised field agriculture in Bolivia and Peru. Pages 181-204 in J. M. Teutonico and F. Matero, editors. Managing change: sustainable approaches to the conservation of the built environment. The Getty Conservation Institute, Los Angeles, California, USA. 
Escobar, A. 1998. Whose knowledge, whose nature? Biodiversity, conservation, and the political ecology of social movements. Journal of Political Ecology 5:53-82.

Future Earth. 2013. What is earth system governance? Interim Secretariat for Future Earth, Paris, France. [online] URL: http:// www.futureearth.info/2013-jul-15/what-earth-system-governance

Gepts, P. 2006. Plant genetic resources conservation and utilization. Crop Science 46:2278-2292. http://dx.doi.org/10.2135/ cropsci2006.03.0169gas

Goldman, M. J., P. Nadasdy, and M. D. Turner, editors. 2011. Knowing nature: conversations at the intersection of political ecology and science studies. University of Chicago Press, Chicago, Illinois, USA. http://dx.doi.org/10.7208/chicago/9780226301440.001.0001

Goldman, M. J., and M. D. Turner. 2011. Introduction. Pages 1-24 in M. J. Goldman, P. Nadasdy, and M. D. Turner, editors. Knowing nature: conversations at the intersection of political ecology and science studies. University of Chicago Press, Chicago, Illinois, USA.

Goodman, M. M., and C. W. Stuber. 1983. Races of maize, VI: Isozyme variation among races of maize in Bolivia. Maydica 28:169-187.

Gray, C. L. 2009. Rural out-migration and smallholder agriculture in the southern Ecuadorian Andes. Population and Environment 30:193-217. http://dx.doi.org/10.1007/s11111-009-0081-5

Hajjar, R., D. I. Jarvis, and B. Gemmill-Herren. 2008. The utility of crop genetic diversity in maintaining ecosystem services. Agriculture, Ecosystems \& Environment 123:261-270. http://dx. doi.org/10.1016/j.agee.2007.08.003

Hecht, S. B., and S. S. Saatchi. 2007. Globalization and forest resurgence: changes in forest cover in El Salvador. BioScience 57:663-672. http://dx.doi.org/10.1641/B570806

Isakson, S. R. 2009. No hay ganancia en la milpa: the agrarian question, food sovereignty, and the on-farm conservation of agrobiodiversity in the Guatemalan highlands. Journal of Peasant Studies 36(4):725-759. http://dx.doi.org/10.1080/03066150903353876

Ishizawa, J. 2006. Cosmovisions and environmental governance: the case of in situ conservation of native cultivated plants and their wild relatives in Peru. Pages 207-224 in W. V. Reid, F. Berkes, and T. Wilbanks, editors. Bridging scales and knowledge systems: concepts and applications in ecosystem assessment. Island, Washington, D.C., USA.

Jackson, L. E., U. Pascual, and T. Hodgkin. 2007. Utilizing and conserving agrobiodiversity in agricultural landscapes. Agriculture, Ecosystems \& Environment 121:196-210. http://dx.doi.org/10.1016/ j.agee.2006.12.017

Jackson, L. E., M. M. Pulleman, L. Brussaard, K. S. Bawa, G. G. Brown, I. M. Cardoso, P. C. De Ruiter, L. García-Barrios, A. D. Hollander, P. Lavelle, E. Ouédraogo, U. Pascual, S. Setty, S. M. Smukler, T. Tscharntke, and M. Van Noordwijk. 2012. Socialecological and regional adaptation of agrobiodiversity management across a global set of research regions. Global Environmental Change 22:623-639. http://dx.doi.org/10.1016/j. gloenvcha.2012.05.002
Jarvis, D. I., A. H. D. Brown, P. H. Cuong, L. Collado-Panduro, L. Latournerie-Moreno, S. Gyawali, T. Tanto, M. Sawadogo, I. Mar, M. Sadiki, N. T.-N. Hue, L. Arias-Reyes, D. Balma, J. Bajracharya, F. Castillo, D. Rijal, L. Belqadi, R. Rana, S. Saidi, J. Ouedraogo, R. Zangre, K. Rhrib, J. L. Chavez, D. Schoen, B. Sthapit, P. De Santis, C. Fadda, and T. Hodgkin. 2008. A global perspective of the richness and evenness of traditional cropvariety diversity maintained by farming communities. Proceedings of the National Academy of Sciences of the United States of America 105:5326-5331. http://dx.doi.org/10.1073/ pnas.0800607105

Jarvis, D. I., T. Hodgkin, B. R. Sthapit, C. Fadda, and I. LopezNoriega. 2011. An heuristic framework for identifying multiple ways of supporting the conservation and use of traditional crop varieties within the agricultural production system. Critical Reviews in Plant Sciences 30:125-176. http://dx.doi. org/10.1080/07352689.2011.554358

Jarvis, D. I., C. Padoch, and H. D. Cooper, editors. 2007. Managing biodiversity in agricultural ecosystems. Columbia University Press, New York, New York, USA.

Jewitt, S. 2000. Unequal knowledges in Jharkhand, India: deromanticizing women's agroecological expertise. Development and Change 31:961-985. http://dx.doi.org/10.1111/1467-7660.00185

Jokisch, B. D. 2002. Migration and agricultural change: the case of smallholder agriculture in highland Ecuador. Human Ecology 30:523-550. http://dx.doi.org/10.1023/A:1021198023769

Kates, R. W., W. C. Clark, R. Corell, J. M. Hall, C. C. Jaeger, I. Lowe, J. J. McCarthy, H. J. Schellnhuber, B. Bolin, N. M. Dickson, S. Faucheux, G. C. Gallopin, A. Grübler, B. Huntley, J. Jäger, N. S. Jodha, R. E. Kasperson, A. Mabogunje, P. Matson, H. Mooney, B. Moore III, T. O'Riordan, and U. Svedin. 2001. Sustainability science. Science 292:641-642. http://dx.doi.org/10.1126/science.1059386

Kay, C. 2008. Reflections on Latin American rural studies in the neoliberal globalization period: a new rurality? Development and Change 39(6):915-943. http://dx.doi.org/10.1111/j.1467-7660.2008.00518. $\underline{x}$

Lambin, E. F., and P. Meyfroidt. 2011. Global land use change, economic globalization, and the looming land scarcity. Proceedings of the National Academy of Sciences of the United States of America 108:3465-3472. http://dx.doi.org/10.1073/ pnas. 1100480108

Larson, B. 1988. Colonialism and agrarian transformation in Bolivia: Cochabamba, 1550-1900. Princeton University Press, Princeton, New Jersey, USA.

Lerner, A. M., and K. Appendini. 2011. Dimensions of periurban maize production in the Toluca-Atlacomulco Valley, Mexico. Journal of Latin American Geography 10:87-106. http:// dx.doi.org/10.1353/lag.2011.0033

Liu, J., T. Dietz, S. R. Carpenter, M. Alberti, C. Folke, E. Moran, A. N. Pell, P. Deadman, T. Kratz, J. Lubchenco, E. Ostrom, Z. Ouyang, W. Provencher, C. L. Redman, S. H. Schneider, and W. W. Taylor. 2007. Complexity of coupled human and natural systems. Science 317:1513-1516. http://dx.doi.org/10.1126/ science. 1144004 
Liverman, D. M., and S. Vilas. 2006. Neoliberalism and the environment in Latin America. Annual Review of Environmental Resources 31:327-363. http://dx.doi.org/10.1146/annurev. energy.29.102403.140729

Lobell, D. B., and M. Burke, editors. 2010. Climate change and food security: adapting agriculture to a warmer world. Springer, Dordrecht, The Netherlands.

Love, B., and D. Spaner, D. 2007. Agrobiodiversity: its value, measurement, and conservation in the context of sustainable agriculture. Journal of Sustainable Agriculture 31(2):53-82. http:// dx.doi.org/10.1300/J064v31n02 05

Mayer, E. 2002. The articulated peasant: household economies in the Andes. Westview, Boulder, Colorado, USA.

Mayer, E. 2004. Casa, chacra y dinero: economías domésticas y ecología en los Andes. Instituto de Estudios Peruanos, Lima, Peru.

Méndez, V. E., C. M. Bacon, M. Olson, K. S. Morris, and A. Shattuck. 2010. Agrobiodiversity and shade coffee smallholder livelihoods: a review and synthesis of ten years of research in Central America. Professional Geographer 62(3):357-376. http:// dx.doi.org/10.1080/00330124.2010.483638

Nabhan, G. P. 2008. Where our food comes from: retracing Nikolay Vavilov's quest to end famine. Island, Washington, D.C., USA.

Oakley, E., and J. H. Momsen. 2005. Gender and agrobiodiversity: a case study from Bangladesh. Geographical Journal 171:195-208. http://dx.doi.org/10.1111/j.1475-4959.2005.00160. $\underline{\mathrm{x}}$

Ostrom, E. 2009. A general framework for analyzing sustainability of social-ecological systems. Science 325:419-422. http://dx.doi.org/10.1126/science.1172133

Perales, R. H., S. B. Brush, and C. O. Qualset. 2003. Dynamic management of maize landraces in Central Mexico. Economic Botany 57:21-34.

Perfecto, I., and J. Vandermeer. 2010. The agroecological matrix as alternative to the land-sparing/agriculture intensification model. Proceedings of the National Academy of Sciences of the United States of America 107:5786-5791. http://dx.doi. org/10.1073/pnas.0905455107

Peterson, G. 2000. Political ecology and ecological resilience: an integration of human and ecological dynamics. Ecological Economics 35:323-336. http://dx.doi.org/10.1016/S0921-8009(00) $\underline{00217-2}$

Plieninger, T., and C. Bieling. 2012a. Connecting cultural landscapes to resilience. Pages 3-26 in T. Plieninger and C. Bieling, editors. Resilience and the cultural landscape: understanding and managing change in human-shaped environments. Cambridge University Press, New York, New York, USA. http://dx.doi. org/10.1017/CBO9781139107778.003

Plieninger, T., and C. Bieling, editors. 2012b. Resilience and the cultural landscape: understanding and managing change in humanshaped environments. Cambridge University Press, New York, New York, USA. http://dx.doi.org/10.1017/CBO9781139107778

Ramírez, E. R., D. H. Timothy, B. E. Díaz, and U. J. Grant. 1960. Races of maize in Bolivia. National Academy of Sciences and National Research Council, Washington, D.C., USA.
Raudsepp-Hearne, C., G. D. Peterson, and E. M. Bennett. 2010. Ecosystem service bundles for analyzing tradeoffs in diverse landscapes. Proceedings of the National Academy of Sciences of the United States of America 107:5242-5247. http://dx.doi. org/10.1073/pnas.0907284107

Reardon, T., J. Berdegué, and G. Escobar. 2001. Rural nonfarm employment and incomes in Latin America: overview and policy implications. World Development 29(3):395-409. http://dx.doi. org/10.1016/S0305-750X(00)00112-1

Reyes-García, V., V. Vadez, T. Huanca, W. R. Leonard, and T. McDade. 2007. Economic development and local ecological knowledge: a deadlock? Quantitative research from a native Amazonian society. Human Ecology 35:371-377. http://dx.doi. org/10.1007/s10745-006-9069-2

Sánchez, J. J., M. M. Goodman, and R. M. Bird. 2006. Isozyme and morphological variation in maize of five Andean countries. Maydica 5:25-42.

Schaich, H., C. Bieling, and T. Plieninger. 2010. Linking ecosystem services with cultural landscape research. GaiaEcological Perspectives for Science and Society 19(4):269-277.

Scherr, S. J., and J. A. McNeely. 2008. Biodiversity conservation and agricultural sustainability: towards a new paradigm of 'ecoagriculture' landscapes. Philosophical Transactions of the Royal Society B: Biological Sciences 363:477-494. http://dx.doi. org/10.1098/rstb.2007.2165

Seto, K. C. 2011. Exploring the dynamics of migration to megadelta cities in Asia and Africa: contemporary drivers and future scenarios. Global Environmental Change 21(Supplement 1):S94S107. http://dx.doi.org/10.1016/j.gloenvcha.2011.08.005

Shriar, A. J. 2010. Destitution through "development": a case study of the Laka Laka Project in Cochabamba, Bolivia. Sustainability 2:3239-3257. http://dx.doi.org/10.3390/su2103239

Smale, M. 2006. Managing crop biological diversity on farms. Pages 79-101 in J. Cooper, L. Lipper, and D. Zilberman, editors. Agricultural biodiversity and biotechnology in economic development. Springer, New York, New York, USA.

Swift, M. J., A.-M. N. Izac, and M. van Noordwijk. 2004. Biodiversity and ecosystem services in agricultural landscapesare we asking the right questions? Agriculture, Ecosystems \& Environment 104:113-134. http://dx.doi.org/10.1016/j.agee.2004.01.013

Trosper, R. L. 2005. Emergence unites ecology and society. Ecology and Society 10(1): 14. [online] URL: http://www. ecologyandsociety.org/vol10/iss1/art14/

Tscharntke, T., A. M. Klein, A. Kruess, I. Steffan-Dewenter, and C. Thies. 2005. Landscape perspectives on agricultural intensification and biodiversity - ecosystem service management. Ecology Letters 8:857-874. http://dx.doi.org/10.1111/ j.1461-0248.2005.00782.x

Turner, M. D. 2013. Political ecology I: an alliance with resilience? Progress in Human Geography, in press. http://dx.doi. org/10.1177/0309132513502770

Turner, B. L., II, E. F. Lambin, and A. Reenberg. 2007. The emergence of land change science for global environmental change and sustainability. Proceedings of the National Academy 
of Sciences of the United States of America 104:20666-20671. http://dx.doi.org/10.1073/pnas.0704119104

Turner, B. L., II, and D. Lawrence. 2012. Land architecture in the Maya lowlands: implications for sustainability. Pages 445-463 in P. Gepts, T. R. Famula, R. L. Bettinger, S. B. Brush, A. B. Damania, P. E. McGuire, and C. O. Qualset, editors. Biodiversity in agriculture: domestication, evolution, and sustainability. Cambridge University Press, New York, New York, USA. http:// dx.doi.org/10.1017/CBO9781139019514.026

Turner, B. L., II, and P. Robbins. 2008. Land-change science and political ecology: similarities, differences, and implications for sustainability science. Annual Review of Environment and Resources 33:295-316. http://dx.doi.org/10.1146/annurev. environ.33.022207.104943

Vandermeer, J., M. van Noordwijk, J. Anderson, C. Ong, and I. Perfecto. 1998. Global change and multi-species agroecosystems: concepts and issues. Agriculture, Ecosystems \& Environment 67:1-22. http://dx.doi.org/10.1016/S0167-8809(97)00150-3

Van der Ploeg, J. D. 2009. The new peasantries: struggles for autonomy and sustainability in an era of empire and globalization. Routledge, London, UK.

Van der Stege, C., B. Vogl-Lukasser, and C. R. Vogl. 2012. The role of homegardens in strengthening social-ecological resilience: case studies from Cuba and Austria. Pages 261-282 in T. Plieninger and C. Bieling, editors. Resilience and the cultural landscape: understanding and managing change in human-shaped environments. Cambridge University Press, New York, New York, USA. http://dx.doi.org/10.1017/CBO9781139107778.019

Vanek, S. J., and L. E. Drinkwater. 2013. Environmental, social, and management drivers of soil nutrient mass balances in an extensive Andean cropping system. Ecosystems 16:1517-1535. http://dx.doi.org/10.1007/s10021-013-9699-3

van Etten, J. 2006. Molding maize: the shaping of a crop diversity landscape in the western highlands of Guatemala. Journal of Historical Geography 32(4):689-711. http://dx.doi.org/10.1016/j. jhg.2005.12.002

van Etten, J., and de Bruin, S. 2007. Regional and local maize seed exchange and replacement in the western highlands of Guatemala. Plant Genetic Resources: Characterization and Utilization 5:57-70. http://dx.doi.org/10.1017/S147926210767230X

van Etten, J., M. R. Fuentes López, L. G. Molina Monterroso, and K. M. Ponciano Samayoa. 2008. Genetic diversity of maize (Zea mays L. ssp. mays) in communities of the western highlands of Guatemala: geographical patterns and processes. Genetic Resources and Crop Evolution 55:303-317. http://dx.doi. org/10.1007/s10722-007-9235-4

Warner, K. 2010. Global environmental change and migration: governance challenges. Global Environmental Change 20 (3):402-413. http://dx.doi.org/10.1016/j.gloenvcha.2009.12.001

Widgren, M. 2012. Resilience thinking versus political ecology: understanding the dynamics of small-scale, labour-intensive farming landscapes. Pages 95-110 in T. Plieninger and C. Bieling, editors. Resilience and the cultural landscape: understanding and managing change in human-shaped environments. Cambridge
University Press, New York, New York, USA. http://dx.doi. org/10.1017/CBO9781139107778.008

Wood, S., and S. Ehui. 2005. Food. Pages 209-241 in R. Hassan, R. Scholes, and A. Neville, editors. Ecosystems and human wellbeing: current states and trends, volume 1. The Millennium Ecosystem Assessment Series, Island, Washington, D.C., USA.

Yarnall, K., and M. Price. 2010. Migration, development and a new rurality in the Valle Alto, Bolivia. Journal of Latin American Geography 9:107-124. http://dx.doi.org/10.1353/lag.0.0083

Zimmerer, K. S. 1995. The origins of Andean irrigation. Nature 378(6556):481-483. http://dx.doi.org/10.1038/378481a0

Zimmerer, K. S. 1996. Changing fortunes: biodiversity and peasant livelihoods in the Peruvian Andes. University of California Press, Berkeley, California, USA.

Zimmerer, K. S. 2010a. Biological diversity in agriculture and global change. Annual Review of Environment and Resources 35:137-166. http://dx.doi.org/10.1146/annurev-environ-040309-113840

Zimmerer, K. S. 2010b. Woodlands and agrobiodiversity in irrigation landscapes amidst global change: Bolivia, 1990-2002. Professional Geographer 62:335-356. http://dx.doi. org/10.1080/00330124.2010.483631

Zimmerer, K. S. 2011. The landscape technology of spate irrigation amid development changes: assembling the links to resources, livelihoods, and agrobiodiversity-food in the Bolivian Andes. Global Environmental Change 21:917-934. http://dx.doi. org/10.1016/j.gloenvcha.2011.04.002

Zimmerer, K. S. 2012. Agrobiodiversity and water resources in agricultural landscape evolution (Andean valley irrigation, Bolivia, 1986 to 2008). Pages 464-474 in P. Gepts, T. R. Famula, R. L. Bettinger, S. B. Brush, A. B. Damania, P. E. McGuire, and C. O. Qualset, editors. Biodiversity in agriculture: domestication, evolution, and sustainability. Cambridge University Press, New York, New York, USA. http://dx.doi.org/10.1017/CBO9781139019514.027

Zimmerer, K. S. 2013. The compatibility of agricultural intensification in a global hotspot of smallholder agrobiodiversity (Bolivia). Proceedings of the National Academy of Sciences of the United States of America 110(8):2769-2774. http://dx.doi. org/10.1073/pnas.1216294110 